\title{
Findings of an International Research on the Future of Marketing Communication
}

\author{
Gábor Rekettye Jr. \\ Metropolitan University, Budapest, Hungary \\ Gábor Rekettye \\ University of Pécs, Pécs, Hungary
}

\begin{abstract}
The objective of the research was to map the most important global megatrends affecting the business and marketing environment and to analyze and understand how the changed environment will affect the practice and performance of marketing communication in the next decade. For identifying the global megatrends, a comprehensive literature review was initiated. For understanding the future changes in marketing communication an experts questionnaire survey was carried out in four countries - Croatia, Finland, Hungary, and India - in 2015. For the purpose of this paper, the data for Croatia, Hungary and India were picked out and analyzed. The research provided the possibility of comparing how experts and opinion leaders from the big emerging, and the two small transition countries evaluated the effects of the global megatrends on business environment, and how they thought the changed business environment would influence the future of marketing communication in their countries. The findings proved that the explored megatrends would have and important - however in the two regions differently evaluated - effect on marketing communication. The content, the used communication tools and the spending on marketing communication are the fields, which will influence the performance of the companies' marketing communication, and where radical changes are expected.
\end{abstract}

Keywords: global megatrends, business environment, development of marketing communication, future performance of marketing, management, market

JEL classification: M30, M31, M37

\section{Introduction}

The practice of marketing and especially marketing communication (MC) has never had a more difficult period in its short history than what it is faced with in our century. The growth of the population along with the factors of globalization and other global trends seriously rewrite the everyday practices of marketers (Egan, 2015, Kotler et al, 2010, Quelch and Jocz, 2009, Vijay, 2009).

The goal of the paper is to report about some important findings of an international research that focused on the possible future of marketing communication. The research intended firstly to map those megatrends, which would shape the future of the business environment in the different regions of the world, and secondly to explore how this changed environment would influence the practice of marketing communication.

The primary research was carried out in three regions (advanced, emerging and transition world). For the purpose of the paper the data obtained from Croatia, Hungary and India are used and analyzed to show the differences and 
concordances of the evaluations of the opinion leaders coming from these two regions.

The structure of the paper is as follows:

- First, the main questions of the research are discussed.

- Then the paper discusses the methodology used in the research.

- The following part of the paper describes the most important findings of the research.

- The paper ends with the conclusions.

\section{The Main Questions of the Research}

The main aim of the research was to explore how the experts from these three countries think about the following issues:

- The intensity of changes in marketing communication in the next decade in their respective countries.

- How they evaluate the strength of the effects of the global megatrends on the future business and marketing environment.

- In the framework of the changed environment how they evaluate the "globalization-localization" issue in the future.

To explore their opinions about the main elements of the marketing communication that will surface in the future due to the changing business environment.

The field of the primary research provided the possibility to compare the differences of the experts' evaluations coming from the two small European transition countries and the big Asian emerging country.

\section{Methodology}

\section{Desk research: Exploring the main megatrends}

To identify the megatrends influencing the future business environment a comprehensive literature review was made. This included comprehensive reports and forecasts made by famous international research institutes and agencies were (Larsen 2006; NIC, 2012; Gregosz, 2012; Vielmetter and Sell, 2014; Hajkowitcz, 2015; Dobbs et al, 2015). Based on these sources, the following six main megatrends were identified:

- Power-shift in the world economy, which means that the economic power is rapidly moving from West to East and South.

- Global climate change, global warming threatening the economy and the society of many countries.

- Demographic trends, aging population in the West and overpopulation and rapid urbanization in the East and South.

- The increasing rate of technological development, especially in the ICT sector.

- The after-effects of the global recession resulting in changing consumer behavior, increasing price sensitivity and value consciousness.

- The trend towards proliferation, i.e. the clutter of new brands and new communication tools. 


\section{Primary research: Mapping the opinions of experts}

For the primary research, a questionnaire survey was used. Based on the experiences of the in-depth interviews with one determining expert from each of the three countries an on-line questionnaire was prepared and tested in Hungarian and English language. It was sent to university professionals and MBA students in Croatia, Hungary, and India. The snowball method was applied. Altogether 262 questionnaires (Croatia - 59, Hungary - 121, India - 82) were received from the three countries. Data was processed using the SPSS software. The distribution of the sample is illustrated in Table 1.

Table 1

The distribution of the sample (\%)

\begin{tabular}{|c|c|c|c|c|c|}
\hline & & Croatia & Hungary & India & Subtotals \\
\hline \multirow{3}{*}{ Occupation } & Business educators & 48.2 & 39.7 & 83.3 & \\
\hline & Students & 14.3 & 18.1 & 3.9 & \\
\hline & Businessmen & 37.5 & 42.2 & 12.8 & 100.0 \\
\hline \multirow{3}{*}{ Age } & Below 35 & 53.6 & 43.1 & 27.3 & \\
\hline & $36-55$ & 37.5 & 35.3 & 54.5 & \\
\hline & Above 55 & 8.9 & 21.6 & 18.2 & 100.0 \\
\hline \multirow[b]{2}{*}{ Gender } & Male & 43.4 & 49.1 & 64.9 & \\
\hline & Female & 56.6 & 50.9 & 35.1 & 100.0 \\
\hline \multirow{2}{*}{$\begin{array}{l}\text { Marketing } \\
\text { Affiliation }\end{array}$} & Yes & 76.8 & 60.3 & 53.8 & \\
\hline & No & 23.2 & 39.7 & 46.2 & 100.0 \\
\hline
\end{tabular}

Source: Own research

\section{Findings}

Since the length of the present study does not allow discussing all the results of the research, only four interesting parts of the findings will be highlighted here.

\section{Evaluation of the respondents about the intensity of changes} The first aim of the questionnaire survey was to learn what respondents thought about the intensity of changes in terms of content and means used in marketing communication in the next decade. Respondents had the option to select from the following four statements: (a) radical changes, (b) gradual changes, (c) minimal changes, and (d) no change at all.

since the frequency of the option 'no change at all' was very low, 'minimal changes' and no changes at all' could be added up giving the possibility to use only three options. The results are shown in Table 2.

\section{Table 2}

Opinions about the intensity of changes in the future of $M C(\%)$

\begin{tabular}{|l|r|r|r|}
\hline Statements & Croatia & \multicolumn{1}{r|}{ Hungary } & \multicolumn{1}{|c|}{ India } \\
\hline No or minimal changes & 3.6 & 15.8 & 2.6 \\
\hline Gradual changes & 60.0 & 42.1 & 31.6 \\
\hline Radical changes & 36.4 & 42.1 & 65.8 \\
\hline Total & 100.0 & 100.0 & 100.0 \\
\hline
\end{tabular}

Source: Own research 
It is interesting to see the differences among the evaluation of the experts coming from the three countries: while the experts from India voted for very radical changes, the experts from the two small European countries forecasted less radically and according to their beliefs changes in the future are likely to be more gradual.

\section{The effects of the megatrends on the business and marketing environment}

A factor analysis was used regarding the questions of the different megatrends described earlier in the paper. It proved that they all have an effect on the business environment in each country. The rankings vary from country to country. An important finding is that the issue of technological development was the most outstanding, due to its nature being able to indirectly influence the other five trends as well. Table 3 lists the rankings of the strength of the six megatrends by countries.

Table 3

Ranking of megatrends by countries ( 1 = most important, 6 = least important)

\begin{tabular}{|l|c|c|c|}
\hline \multirow{2}{*}{ Megatrends } & \multicolumn{3}{c|}{ Rankings from 1 to 6. } \\
\hline Technological development & 1 & Hungary & India \\
\hline Global climate change & 3 & 1 & 1 \\
\hline Effect of the crisis on consumer behaviour & 2 & 3 & 3 \\
\hline Effect of the power shift & 6 & 2 & 6 \\
\hline Demographic changes & 4 & 6 & 5 \\
\hline Brand proliferation & 5 & 5 & 2 \\
\hline
\end{tabular}

Source: Own research

The striking difference is in the row of "crisis". It shows that in both Croatia and Hungary the business environment still suffers from the after effects of the global recession. Both agreed with the statement that the consumer behavior has radically changed and the consumers became very much price sensitive. The fact that Indians' responses put this issue at the last place shows that they did not and do not suffer so much from the after effects of the recession.

There is also a striking difference in the "demography" issue. Both Hungary and Croatia is experiencing a rapid ageing of the population, which will later influence the marketing and marketing communication activity. The old age dependency ratio (65+/(15-64) in 2010 was already $23.7 \%$ in Europe compared to India's figure of 7.7\% (EC, 2014). In India, the demographic issues have different aspects: overpopulation as a negative effect and rapid urbanization as a positive effect on the business environment.

It is also intriguing that power shift, which is the expectation of the world economists, implicating that wealth is rapidly moving from West to East was considered not so important from the part of the Croatian and Hungarian respondents.

\section{Opinions about the issue of globalization vs. localization of MC} The respondent from the three distinct countries were asked about the globalization contra localization issue. Two questions were asked with a five point Likert scale. The question was coined as follows: "Due to cultural differences marketing communication will mostly stay localized". Adding up the "partially agree" and the "completely agree" categories under the term Agree and facing them with sum of "Strongly disagree, partially disagree and the neutral" categories, titled Not agree, the following result were observed (Figure 1). 
Figure 1

The country differences on the agreements with localization (\%)

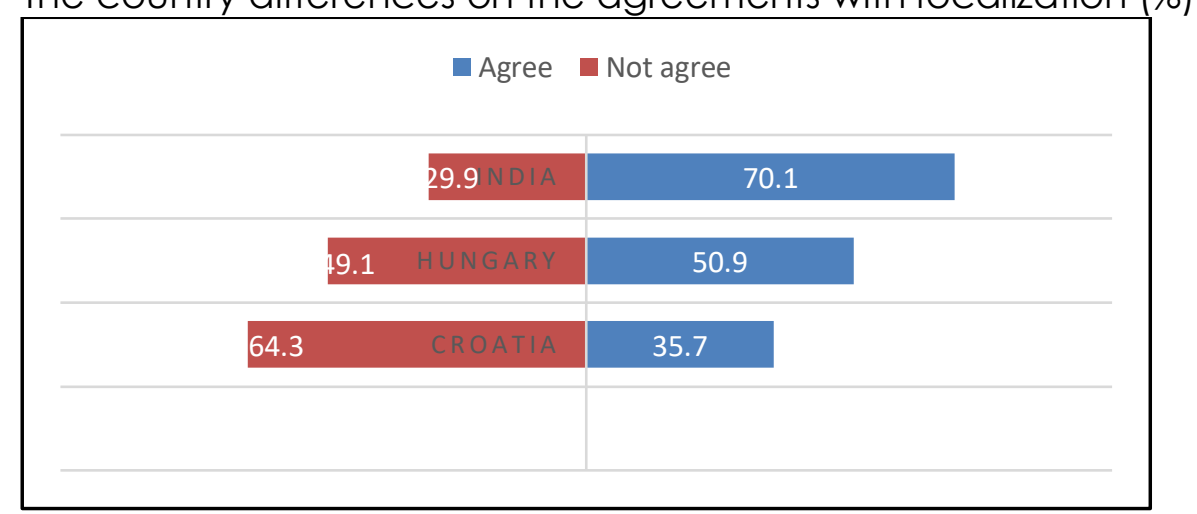

Source: Authors' illustration

The data properly reflects the debate that is going on in the practice of multinational companies or even in the marketing literature. Nevertheless, our data shows that while the balance between "Agree" and "Not agree" is in Hungary is around $50-50 \%$, the Croatians voted for globalization, and the Indians for localization. The Indians' attitude is quite understandable: the growing Indian consumer market is rather fragmented. The cultural diversity of the Indian people, differences of languages, differences in tastes, and habits would make it very difficult for companies to work with a globalized scheme of marketing communication (Kumar, 2009; Kurl, 2015).

It means that if the forecasts about the global economic power-shift will come true and a strong middle class will develop in the emerging world - first of all in China and India - localization of the marketing communication will be a kind of precondition of the market success.

4. The effects of the changed business and marketing environment on marketing communication

The majority of the respondents believed that the changed business and marketing environment would change first the content and second the tools of marketing communication. Besides, this changing environment will require a higher expenditure on marketing communication. It looks evident that the climate change, the changing consumer behavior and the power shift have a bigger effect on the content of communication while the proliferation of brands and communication tools and the development of the digital technology will change the tools applied in marketing communication.

As far as the future of MC content is concerned, the findings were the following:

- MC of the future would be more emotional and authentic and less rational.

- Consumers would have more roles in generating the content.

- Environmental awareness would have more importance in the content

- Brand image related content would dominate MC.

As far as the classical tools of MC (advertising, PR, sales promotion, personal selling and direct marketing) are concerned in next decade the survey proved:

- Indians see a radical increase in all the five tools of the classic marketing communications mix.

- The other two countries forecast stagnation in advertising, a moderate increase in personal selling, and higher increase in PR, sales promotion and direct marketing. 
The new tools of MC (guerrilla marketing, social media, mobile, online) will play an increasingly important role in the next decade according most of the respondents from all counties surveyed in the research.

\section{Conclusion}

Forecasts predict radical changes in the global world economy. The developing countries are likely to continue in the path of economic growth. This change along with the megatrends discussed in the paper, especially the technological advances will fundamentally change the practice of marketing communications in the next decade. Changes are likely to affect the content, the tools and the money spent on different marketing means.

The findings of the research predict noteworthy differences among the experts' opinions coming from the two transition economies and those coming from India. Opinions about the future of marketing communication in these two countries are less radical, then that of the Indians. This may be regarded as a warning for these two small European countries. Given that companies of these two countries aim to succeed in this new multipolar world, exploring the new possibilities offered by the growing emerging markets means that they will have to adapt their marketing activities to the local environments of these markets. The difficulty of this from a managerial aspect is that these emerging countries present new challenges, especially in terms of cultural differences. Marketing communication is the most sensitive area of the businesses, since it meets the customer first.

The research has certain limitations, for example, the sample size, but it also lays out new directions for further research.

\section{References}

1. Dobbs, R., Manyika, J., Woetzel, J. (2015), No ordinary disruption, Public Affairs, New York

2. European Commission (2014) The 2015 Ageing Report, Underlying Assumptions and Projection Methodologies, EUROPEAN ECONOMY 8|2014

3. Egan, J (2015), Marketing Communications, Sage Publications, London, UK

4. Gregosz, D. (2012), Economic Megatrends up to 2020, Konrad Adenaver Stiftung, Berlin

5. Hajkowicz, S. (2015) Global Megatrends - Seven patterns of change shaping our future, CSIRO Publishing, Australia

6. Kotler, P., Kartajaya, H. and Setiawan, I. (2010), Marketing 3.0, Wiley, Hoboken, NJ.

7. Kumar, S. R. (2009), "Adapting IMC to Emerging Markets: Importance of Cultural Values in the Indian Context", J. of Integrated Marketing Communications, 2009 pp. 38-42,

8. Kurl, D. (2015), "Understanding Integrated Marketing Communication in India", http://www.exchange4media.com/viewpoint/viewpoint.asp? view_id=95

9. Larsen, $G$ (2006), Why megatrends matter, Copenhagen Institute for Future Studies

10. NIC (National Intelligence Council) (2008) Global Trends 2025: A Transformed World, Washington, DC

11. Quelch, J. A. and Jocz, K. E. (2009) "How to market in downturn', Harvard Business Review, April, Reprint R0904D.

12. Vielmetter, G., Sell, Y. (2014) Leadership 2030: The Six Megatrends You Need to Understand to Lead your Company into the Future, Hay Group Holding Inc. New York

13. Vijay, C. (2009),"Marketing Strategy for the 21st Century", Journal of Marketing \& Communication, Vol. 5.Issue 1. pp. 88-91. 


\section{About the authors}

Gábor Rekettye Jr. is an Assistant Professor at the Metropolitan University Budapest. He received his Master's in Marketing Management from Middlesex University, London, UK. His teaching career began at the Faculty of Business and Economics of the University of Pécs. Currently, he works at the Metropolitan University, where his responsibilities include directing the Marketing Workshop for talented students. Besides the number of articles written in the field of marketing, he is currently a PhD candidate at the Széchenyilstván University, Győr. The author can be contacted at: grekettye@metropolitan.hu.

Gábor Rekettye is a Professor Emeritus at the University of Pécs. He received his Master degree from Budapest University of Economics, and his PhD degree from the Hungarian Academy of Sciences, both in Economics. He is the author of several textbooks, which are taught at different universities in Hungary. In addition, he has written around 300 publications in Hungary and abroad. In his carrier, he was working in the industry, in foreign trade, and for five years, he has served as the Commercial Counselor of Hungary in Tokyo, Japan. Between 1993 and 1996, he was the Dean of the Business School. In 2003, he received the highest scientific title in Hungary, 'The Doctor of the Hungarian Academy of Sciences'. The author can be contacted at rekettye@ktk.płe.hu. 